\title{
Spark Ignition Vehicle Contributions to Atmospheric Fine Elemental Carbon Concentrations in Coastal, Rural and Urban Communities using Polycyclic Aromatic Hydrocarbon Tracers in the CMB Model Modified for Reactivity
}

\author{
Arantzazu Eiguren-Fernandez and Antonio H. Miguel ${ }^{*, \#}$ \\ Nanoparticle Chemistry Laboratory and Southern California Particle Center \& Supersite, Institute of the Environment, \\ University of California, 90095-1772, Los Angeles-CA, USA
}

\begin{abstract}
Repartimos a parcela do componente de carbono elementar (CE) em $\mathrm{PM}_{2.5}$ atmosférico atribuível à emissões de veículos com ignição por faísca (SI) em amostras coletadas durante dois anos em doze comunidades no Sul da Califórnia, incluindo zonas costeiras, rurais e urbanas usando o Modelo de Balanço de Massa Química (CMB8) modificado para levar em conta a reatividade dos hidrocarbonetos policíclicos aromáticos (HPAs). Foram avaliadas as razões HPA/CE em amostras coletadas no túnel Caldecott para utilização como assinaturas das fontes. A reatividade dos HPAs que ocorre durante o transporte de aerossóis atmosféricos que pode afetar as estimativas de contribuição das fontes (ECF) durante o verão/primavera/outono foi considerada com o uso de constantes de decaimento medidas experimentalmente. Nossos resultados mostram que o benzo[ $\mathrm{ghi}]$ perylene e o indeno[1,2,3-cd] pireno podem ser utilizados com sucesso como marcadores específicos de CE nas emissões por veículos com SI. A estimativa média da porção de CE atribuído pelo modelo à emissões provenientes de SI nessas comunidades foi de 39,58 e $62 \%$, respectivamente, durante o verão, primavera/outono, e inverno. Para todas as comunidades costeiras, as atribuições a veículos por SI representam cerca do dobro das estimativas para as áreas rurais e urbanas, antes de dezembro 2003 quando MTBE ainda era usado na California.
\end{abstract}

We apportioned the elemental carbon (EC) component of ambient $\mathrm{PM}_{2.5}$ attributable to emissions from spark ignition (SI) vehicles in samples collected over a three-year period in twelve Southern California communities, including coastal, rural, and urban areas using the chemical mass balance model (CMB8) modified for polycyclic aromatic hydrocarbon (PAH) reactivity. Selected PAH/EC ratios, measured in samples collected in the Caldecott tunnel were evaluated for use as fingerprints. PAH reactivity which occurs during atmospheric transport and affects the source contribution estimates during the summer/fall/spring months was accounted for using experimentally measured decay constants. Results showed that benzo[ghi]perylene and indeno[1,2,3-cd]pyrene can be used successfully as specific tracers of EC contributions from SI vehicles. The average EC portion of $\mathrm{PM}_{25}$ attributed by the model to SI emissions at these communities was 39,58 and $62 \%$, respectively, during the summer, spring/autumn, and winter. For all seasons, coastal community contributions represent about twice those found in the rural and urban inland communities, before December 2003 when MTBE was still in use in California.

Keywords: elemental carbon source apportionment, polycyclic aromatic hydrocarbons, spark ignition vehicles, $\mathrm{PM}_{2.5}$, chemical mass balance, MTBE

\section{Introduction}

Elemental carbon (EC) present in the atmospheric aerosol of urban and heavily industrialized locations constitutes a major component of the products of incomplete combustion (PICs) from liquid, solid and

*e-mail: ahmiguel@ucla.edu; amiguel@arb.ca.gov

"Present address: Haagen-Smit Laboratory, California Air Resources Board, 9528 Telstar Avenue, El Monte, CA, 91731, USA. gaseous fuels. Sources of EC in urban areas include spark ignition (SI) and compression ignition (CI) vehicular emissions, PICs generated from energy production and industrial combustion processes, tires, lubricating oil, railroad engines, boilers, aircraft, food cooking, biomass burning and many other processes that burn fossil fuel. ${ }^{1,2}$ In the city of Los Angeles, fine elemental carbon $(\mathrm{dp}<2.5 \mu \mathrm{m})$ account for $30-50 \%$ of the fine particle mass concentration. ${ }^{4}$ The largest source contributors to $\mathrm{PM}_{2.5}$ concentrations in 
Los Angeles include diesel engine (CI) exhaust, paved road dust, gasoline-powered (SI) vehicle exhaust, and emissions from food cooking and wood smoke, with smaller contribution from tire dust, plant fragments, natural gas combustion aerosol, and cigarette smoke ${ }^{5}$ with the dominant sources composed of CI from both on-highway and off-highway applications. ${ }^{6}$

Previous studies have reported that about one-half of the global atmospheric EC emission is estimated to derive from fossil fuel combustion. ${ }^{7}$ Moreover, EC is thought to be one of the principal contributors to the aerosol forcing of climate change. ${ }^{8-10}$ As a component of the atmospheric carbonaceous aerosol, EC also plays an important role in visibility reduction. ${ }^{9}{ }^{11}$ In addition, it has been used to help improve our understanding of the impact of vehicular and other emissions sources on air quality ${ }^{12}$ and health effects, and to monitor occupational exposure to SI and CI particulate matter. ${ }^{13}$

EC and the associated PAH components are ubiquitous in PICs ${ }^{14-16}$ and are mainly associated with fine, ultrafine, and nanoparticles in the $10-32 \mathrm{~nm}$ size range. ${ }^{16-18}$

Research conducted in our laboratory has focused on the effects of fine and ultrafine (nano) particles present in ambient air on health effects. ${ }^{19}$ On going studies at the Southern California Particle Center and Supersite (SCPCS) and the Southern California Environmental Health Sciences Center (SCEHSC) are aimed at evaluating possible correlations between EC and PAH content of the urban aerosol with indicators of in-vitro oxidative stress. $^{20,21}$

Several high molecular weight PAHs (5-7 rings) associated with the atmospheric aerosol are considered carcinogenic and/or mutagenic. PAH profiles and emissions strength vary depending on their source. .,2,22,23 $^{2}$ The ubiquity and similar emission sources of EC and PAHs creates a unique opportunity to use PAHs as source signatures in receptor modeling. ${ }^{15}$ One such model, the Chemical Mass Balance (CMB) developed independently by Sheldon Friedlander in the early 70's, has been widely used for source apportionment using a variety of inorganic and organic tracers. ${ }^{24-26}$ Beginning in 1986 researchers suggested that certain PAHs may be used as tracers in receptor modeling. ${ }^{15}$

In this study we use the CMB8 model to estimate the EC component of $\mathrm{PM}_{2.5}$ attributable to spark ignition (SI) vehicles in twelve Southern California communities, during all seasons over a three-year period, by testing and selecting specific PAHs as tracers of SI vehicular emissions. The results are discussed in terms of: $(i)$ the choice of PAH tracer; (ii) the effect of the location; (iii) the seasonal effect; and, (iv) the daily variability.

\section{Experimental}

\section{Sample collection and chemical analysis}

Atmospheric $\mathrm{PM}_{2.5}$ samples were collected over a period of thirty months (May 2001-October 2003) in three types of communities: coastal, rural inland, and urban inland communities (Figure 1). Details of sample collection are described elsewhere. ${ }^{27}$ Briefly, $\mathrm{PM}_{2.5}$ samples were collected at each site using individual Tisch model 1202 samplers (Cleves, OH, USA), for $24 \mathrm{~h}$ periods, on quartz fiber filters (QFF), at a flow rate of $113 \mathrm{lpm}$. EC was quantified in a $1 \mathrm{~cm}^{2}$ punch of the QFF samples using a thermo-optical analyzer (Sunset Lab Inc., Oregon, USA) following the NIOSH 5040 procedure describe elsewhere. ${ }^{16,28}$ Details of the PAH quantification procedure are described elsewhere. ${ }^{27,29}$ Samples for PAH quantification were extracted from the QFFs by ultrasonication using dichloromethane:acetonitrile $(2: 1, \mathrm{v} / \mathrm{v})$ for 24 minutes $(3 \times 8 \mathrm{~min})$. The extracts were filtered and their volumes reduced to ca. $100 \mu \mathrm{L}$ at room temperature. Selective HPLC-Fluorescence was used to quantify 15 PAHs. The 5 PAHs tested as markers for the CMB8 model are listed in Table 1, along with their codes, molecular weight (MW), sub-cooled liquid vapor pressure, SI fractional concentration (source signature), and reactivity. PAH and EC profiles obtained in the Caldecott tunnel in 1996, and used in the present study, are reported elsewhere. ${ }^{1}$

Table 1. PAH code, molecular weight, sub-cooled vapor pressure (atm), SI signatures and experimentally determined PAH reactivity factors

\begin{tabular}{|c|c|c|c|c|c|}
\hline PAH & Code & MW & $\left(\log \mathrm{p}_{\mathrm{L}}^{\mathrm{o}}\right)^{\mathrm{a}}$ & $\mathrm{F}^{\mathrm{b}}$ & $\alpha_{i j}^{c}$ \\
\hline $\begin{array}{l}\text { Benzo }[b] \\
\text { fluoranthene }\end{array}$ & $\mathrm{BBF}$ & 252 & -9.63 & $0.515 \times 10^{-3}$ & 0.65 \\
\hline Benzo $[a]$ pyrene & BAP & 252 & -10.0 & $0.215 \times 10^{-3}$ & 0.15 \\
\hline $\begin{array}{l}\text { Indeno }[1,2,3-c d] \\
\text { pyrene }\end{array}$ & IND & 276 & -10.0 & $0.320 \times 10^{-3}$ & 0.51 \\
\hline $\begin{array}{l}\text { Dibenz[a,h] } \\
\text { anthracene }\end{array}$ & DBA & 278 & -10.7 & $0.542 \times 10^{-3}$ & 0.57 \\
\hline Benzo $[g h i]$ perylene & BGP & 276 & -10.7 & $0.605 \times 10^{-3}$ & 0.47 \\
\hline
\end{tabular}

\section{Chemical mass balance model}

The chemical composition of the emissions from individual sources can be used to estimate source contributions to atmospheric samples taken at receptor air monitoring sites. ${ }^{30,31}$ The CMB model used in this study, together with the instruction, was obtained from the USEPA web site http://www.epa.gov/scram001/tt23.htm. 


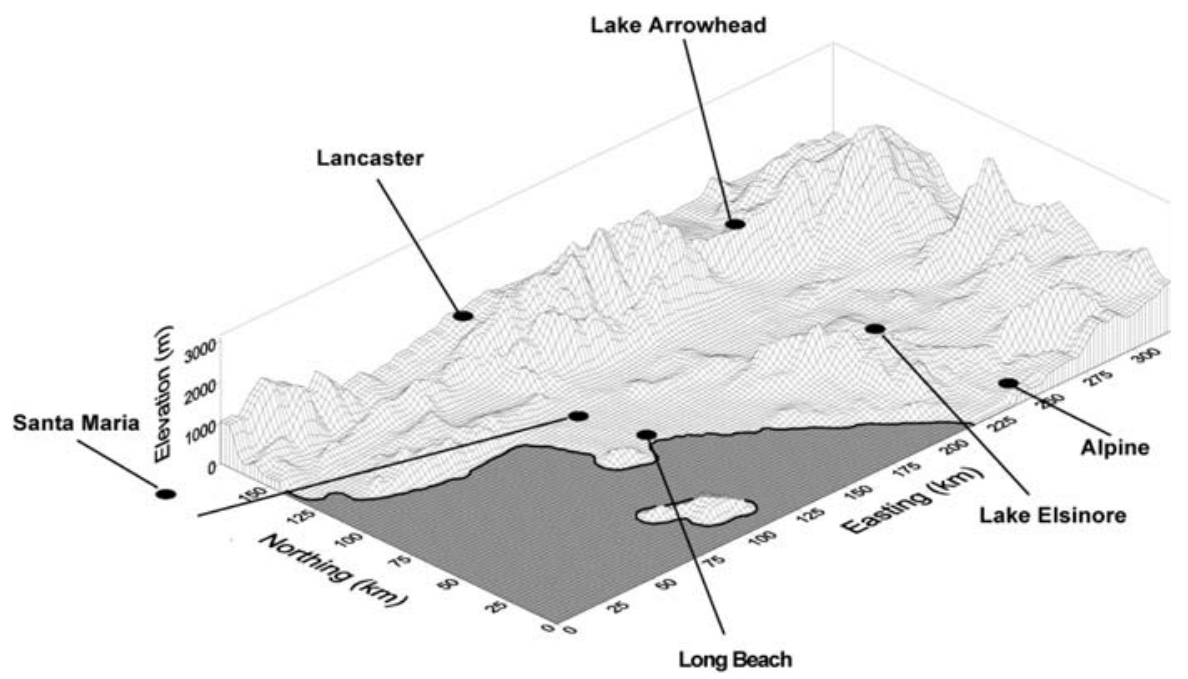

Figure 1. Location of six of the twelve Southern California Children's Health Study communities in coastal, and inland urban and rural areas. Atascadero, not sown in the map, is located ca. $70 \mathrm{Km}$ north of Santa Maria.

In this model, the total ambient mass concentration $\mathrm{C}_{\mathrm{i}}$ of a specie i measured at a receptor site is expressed mathematically as:

$\mathrm{C}_{\mathrm{i}}=\Sigma\left(\mathrm{S}_{\mathrm{j}} \mathrm{F}_{\mathrm{ij}}\right)+\mathrm{E}_{\mathrm{i}}$

where $F_{i j}$ is the fraction of specie $i$ in the emissions from source $\mathrm{j}, \mathrm{S}_{\mathrm{j}}$ is the total mass concentration contributed by source $\mathrm{j}$ at the receptor site, and $\mathrm{E}_{\mathrm{i}}$ represents random errors in the measurement of $\mathrm{C}_{\mathrm{i}}$ and $\mathrm{F}_{\mathrm{ij}}$ or unaccounted-for sources. As PAHs are know to react during atmospheric transport, and to overcome the implicit inert species assumption in the above equation, a reactivity factor, $\alpha$, is included in the equation. The revised mass balance equation $^{24}$ is given by:

$\mathrm{C}_{\mathrm{i}}=\Sigma\left(\mathrm{S}_{\mathrm{j}} \mathrm{F}_{\mathrm{ij}} \alpha_{\mathrm{ij}}\right)+\mathrm{E}_{\mathrm{i}}$

where $\mathrm{C}_{\mathrm{i}}, \mathrm{F}_{\mathrm{ij}}$ and $\mathrm{S}$, have the same meaning as the parameters used in equation $1, \alpha_{\mathrm{ij}}$ is the decay factor of specie $\mathrm{i}$ for source $\mathrm{j}$ expressed as the ratio of receptor concentration to the source concentration normalized to mass:

$\alpha_{\mathrm{ij}}=1 /\left(1+\mathrm{k}_{\mathrm{ij}} \tau_{\mathrm{j}}\right)$

where $\mathrm{k}_{\mathrm{ij}}$ is the decay constant for specie $\mathrm{i}$, and $\tau_{\mathrm{j}}$ is the average residence time in the atmosphere.

To account for decay during atmospheric transport, we reduced our individual PAH source signatures (Table 1), by experimentally calculated decay losses observed for Caldecott tunnel samples collected on filters subsequently exposed to particle-free Los Angles ambient air, under prevailing atmospheric conditions for a period up to $100 \mathrm{~h} .{ }^{32}$

\section{Results and Discussion}

\section{Choice of PAH tracers}

The emission profiles of ten PAHs measured in Bores 1 and 2 of the Caldecott tunnel ${ }^{1}$ from SI and CI emissions, including fluoranthene, pyrene, benzo $[a]$ anthracene, chrysene, benzo $[b]$ fluoranthene, benzo[ $k]$ fluoranthene, benzo $[a]$ pyrene, indeno[ $[1,2,3-c d]$ pyrene, dibenz $[a, h]$ anthracene and benzo[ghi]perylene are shown in Figure 2. It is clear that the PAHs with lower MW (FLT, PYR, BAA and CRY) are not suitable choices, as the fraction of $\mathrm{EC}$ from CI emissions are larger or close to those from SI emissions. For this reason, we tested different combinations of the remaining PAHs (Table 2) using the CMB model with the fractional concentrations listed in Table 1. As no reaction occurs at the tunnel no reactivity coefficient was included in these calculations.

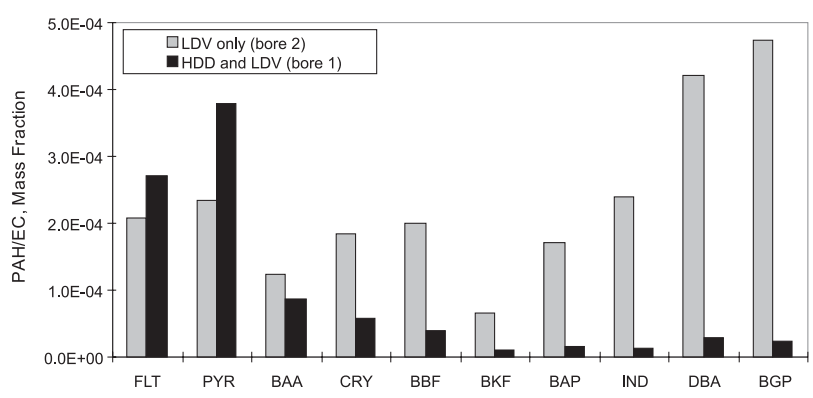

Figure 2. PAH/EC mass fraction for spark ignition (SI) and compression ignition (CI) emissions measured in $\mathrm{PM}_{2}$ collected in the Caldecott Tunnel ${ }^{1}$.

Bore 1 of the Caldecott tunnel represents a mixed fleet of SI and CI, while Bore 2 is only open to SI traffic. Samples from Bore 1 were collected during time periods when the 
Table 2. Average estimated contributions to EC (\%) from SI emissions in $\mathrm{PM}_{2.5}$ samples collected in the Caldecott tunnel using different PAH tracer combinations

\begin{tabular}{lccc}
\hline $\mathrm{n}^{\mathrm{a}}$ & Tracers & Bore $1^{\mathrm{b}}$ & Bore $2^{\mathrm{c}}$ \\
\hline 5 & BBF BAP IND DBA BGP & $6.2 \pm 1.3$ & $87 \pm 8.5$ \\
4 & BAP IND DBA BGP & $5.5 \pm 1.1$ & $100 \pm 12$ \\
3 & BAP IND BGP & $5.3 \pm 1.0$ & $99 \pm 17$ \\
2 & BAP BGP & $6.1 \pm 1.0$ & $101 \pm 17$ \\
2 & IND BGP & $4.7 \pm 1.6$ & $98 \pm 12$ \\
\hline
\end{tabular}

${ }^{a}$ number of tracers used in the apportionment. ${ }^{b}$ Bore 1: SI and CI vehicles (ca. 5\% CI, 95\% SI, average for three measurements). 'Bore 2: Restricted to SI vehicles (average for two measurements).

CI mix was at its highest for the day (ca. 5\%). The source contribution estimate (SCE) that best reflects the actual tunnel fleet traffic mix is obtained using IND and BGP as tracers, respectively $4.7 \%$ and $98 \%$ of EC contributions in Bores 1 and 2 (Table 2).

Other PAH tracer combination that yielded accurate SCEs included BAP and DBA, but were discarded as candidates for source apportionment of field samples because $\mathrm{BAP}$ is the most reactive $\mathrm{PAH}$ in the group, and ambient concentrations of DBA are in general very low. The use of BGP as a vehicular tracer in the CMB model has been reported previously. ${ }^{30,33}$ Thus, in the present study, IND and BGP were used as tracers to estimate the EC contributions to $\mathrm{PM}_{2.5}$ attributed by the model to SI emissions in coastal, rural inland and urban inland communities in Southern California.

\section{Spatial variability}

Communities were grouped based on their population and geographical characteristics in costal, rural inland and urban inland (Table 3). The estimated EC source contribution by SI emissions to the $\mathrm{PM}_{2.5}$ component varies significantly among group, with highest all-season average contributions observed in coastal communities $(52.7 \%)$. Urban and rural inland communities showed similar all-season average contributions of SI emissions to the EC burden with $27.7 \%$ and $24.9 \%$, respectively. Average all-season contributions in coastal communities vary approximately by a factor of two from the inland communities (Table 3), regardless of season. Except for Long Beach, the coastal communities have little or no industrial emission sources. Atascadero, a community highly impacted by traffic from the nearby freeway, showed the highest all-season average contribution (62.3\%), while Lake Arrowhead, a rural community located at high altitude, had the lowest all-season average contribution of all sites (16.5\%). The relatively lower SCEs observed in Riverside and Miraloma, located the furthest downwind from the metropolitan Los Angeles, suggest a larger impact from other EC sources such as CI emissions, local industries and atmospheric transport. It is noteworthy to mention that, over the last decade, the urban inland communities of Upland, Mira Loma, and Riverside are home to numerous warehouse distribution centers serviced by thousands of heavy-duty diesel trucks (CI) each day.

Table 3. Estimates of SI vehicles emission contributions to $\% \mathrm{EC}$ in $\mathrm{PM}_{2.5}$

\begin{tabular}{|c|c|c|c|c|}
\hline & Spring/fall & Summer & Winter & All-season site average \\
\hline \multicolumn{5}{|c|}{ Coastal communities } \\
\hline Lompoc & $30.6 \pm 28$ & $55.4 \pm 30$ & $49.1 \pm 21$ & $45.0 \pm 26$ \\
\hline Santa Maria & $81.4 \pm 20$ & $30.6 \pm 17$ & $49.1 \pm 30$ & $53.7 \pm 22$ \\
\hline Atascadero & $61.9 \pm 26$ & $50.6 \pm 15$ & $74.3 \pm 23$ & $62.3 \pm 21$ \\
\hline Long Beach & $56.9 \pm 35$ & $18.3 \pm 9.1$ & $73.9 \pm 39$ & $49.7 \pm 27$ \\
\hline Season average & $57.7 \pm 21$ & $38.7 \pm 17$ & $61.6 \pm 14$ & $52.7 \pm 17$ \\
\hline \multicolumn{5}{|c|}{ Rural inland communities } \\
\hline Lancaster & $36.0 \pm 37$ & $9.70 \pm 10$ & $\mathrm{n} / \mathrm{a}$ & $22.9 \pm 23$ \\
\hline Lake Arrowhead & $26.7 \pm 24$ & $3.43 \pm 2.7$ & $19.4 \pm 19$ & $16.5 \pm 15$ \\
\hline Lake Elsinore & $45.4 \pm 34$ & $19.3 \pm 8.8$ & $24.2 \pm 25$ & $29.6 \pm 23$ \\
\hline Alpine & $57.5 \pm 27$ & $17.6 \pm 13$ & $17.2 \pm 11$ & $30.8 \pm 17$ \\
\hline Season average & $41.4 \pm 13$ & $12.0 \pm 7.4$ & $20.3 \pm 3.6$ & $24.9 \pm 8.0$ \\
\hline \multicolumn{5}{|c|}{ Urban inland communities } \\
\hline San Dimas & $35.0 \pm 15$ & $16.9 \pm 9.4$ & $37.5 \pm 19$ & $29.8 \pm 14.5$ \\
\hline Upland & $16.4 \pm 10$ & $19.3 \pm 15$ & $36.6 \pm 23$ & $24.1 \pm 16.0$ \\
\hline Mira Loma & $22.6 \pm 13$ & $26.5 \pm 14$ & $46.8 \pm 39$ & $32.0 \pm 22.0$ \\
\hline Riverside & $24.0 \pm 16$ & $16.5 \pm 8.2$ & $34.2 \pm 22$ & $24.9 \pm 15.4$ \\
\hline Season average & $24.5 \pm 7.7$ & $19.8 \pm 4.6$ & $38.8 \pm 5.5$ & $27.7 \pm 6.0$ \\
\hline
\end{tabular}

n/a: data did not converge to reasonable values. 


\section{Seasonal variability}

Samples were arranged in three different seasons: spring/autumn, summer, and winter, depending on the average ambient temperature. Average seasonal contributions for each community and group are shown in Table 3. The contribution by SI emissions in the costal communities varies from $18.3 \%$ in Long Beach during the summer to $81.4 \%$ in Santa Maria during spring/fall. For rural inland communities SCEs vary between $3.43 \%$ for Lake Arrowhead during summer, and $57.5 \%$ for Alpine during spring/fall. Among the urban inland communities Miraloma was the highest with SI contributing up to $46.8 \%$ during winter; Riverside and Upland presented the lowest contributions with $c a .16 .5 \%$ during summer and spring/ fall, respectively.

In general, coastal and urban inland communities showed higher SI contribution during the winter period, while spring/fall showed higher contributions for the rural inland communities.

Seasonal difference between coastal and inland sites in southern California has been reported and explained by Gray et al., ${ }^{4}$ and our results are similar to previous estimates reported by Manchester-Neesvig et al., ${ }^{34}$ and Riddle et al. $^{35}$ who reported a $14-21 \%$ contribution to $\mathrm{PM}_{0.1}$ EC by gasoline combustion (SI) products and motor oil combustion products (5-6\%). The observed differences in the estimated SI contribution to EC during the three seasons may have resulted from several factors, including: (i) meteorology, (ii) a decrease in the number of SI on the road during summer, (iii) higher than-accounted-for photochemical PAH reactions during spring and summer, and (iv) increased emissions from sources that also contribute to atmospheric BGP (e.g. fire places) when the ambient temperature becomes cooler as winter approaches. In the winter, the net air mass movement is toward the offshore direction, placing sites like Long Beach downwind of the city when wind speeds are slow and early morning surface temperature inversions are common. During the summer, the prevailing wind direction is reversed and strong on-shore flow transports the aerosol masses from the Los Angeles Basin deep into the inland communities and mountains. Vehicular cold starts during winter are known to increase exhaust aerosol emissions, a factor that may contribute significantly to the higher SCE values estimated for the urban sites during spring/fall and winter. Although one might think that during winter wood burning may be an important source of BGP, the contribution of this source to the total BGP burden is not significant. ${ }^{36}$

While newer CI engines and improved diesel fuels may have reduced EC levels found a decade ago, the lowest
EC estimates attributable to SI emissions indicate that $\mathrm{CI}$ emissions remain the major source of fine particle EC emissions.

\section{Daily variability}

Sample collection occurred every 8th day, allowing the evaluation of possible day-of-the-week effects on the SI contribution to EC from SI emissions (Figure 3). In general, communities highly impacted by local commuters, or significant daily activities such as Santa Maria and Long Beach, did not show significant differences between weekdays and weekends (Figure 3). In communities such as Lake Elsinore, or communities impacted by weekdays HDD shipment traffic such as Riverside and San Dimas, the contribution of SI vehicles to the EC burden appeared to be more important during weekends.

\section{Conclusions}

The CMB model has been applied to estimate spark ignition (SI) vehicle emissions to the atmospheric elemental carbon contained in $\mathrm{PM}_{2.5}$ using IND and BGP as specific tracers. Our estimated season-averaged fraction of EC $(19.8 \%)$ attributable by the model to light duty vehicles during the summer months in urban inland communities agrees well with the $14-21 \%$ found for ultrafine PM reported by Riddle et al. ${ }^{35}$ for summer measurements using benzo(ghi)perylene+coronene as tracers of SI emissions downwind of a roadway in San Diego, California, located ca. $120 \mathrm{~km}$ to the south of Los Angeles. We conclude that, at the communities studied and communities with similar major EC emission sources, BGP and IND may be used as tracers in the $\mathrm{CMB}$ model, corrected for reactivity during the spring/fall and summer seasons, to apportion the EC component attributable to spark ignition emissions. The model also showed both seasonal and spatial variability based on traffic intensity and geographical conditions. Regional off-shore transport during warmer seasons and onshore transport during the winter months may have an effect in the extent of EC apportionment to SI emissions. Daily variability appeared to be only important in communities also impacted by CI emissions, before the ban of MTBE.

\section{Acknowledgments}

The authors thank the respective school districts and schools participating in the Children Health Study (California Air Resources Board Contract A033-186) for their cooperation and use of facilities, Ed Avol and Suresh Thurairatnam for sample collection during the SCPCS PAH 
a) Riverside

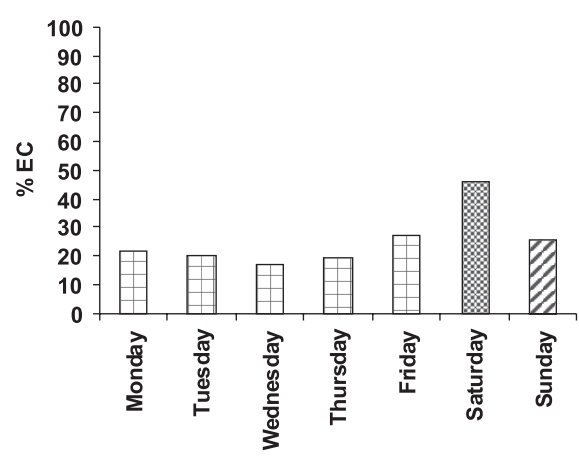

c) Lake Elsinore

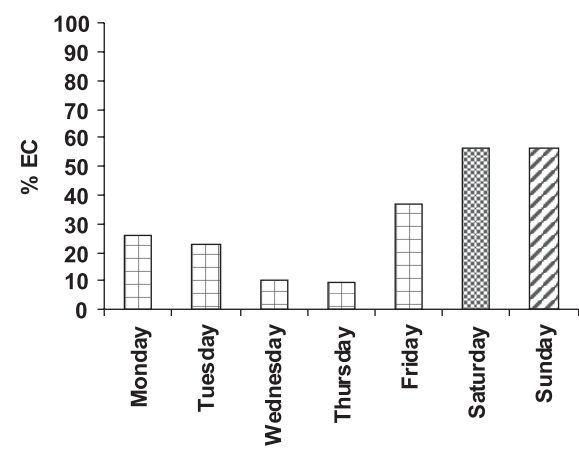

e) Santa Maria

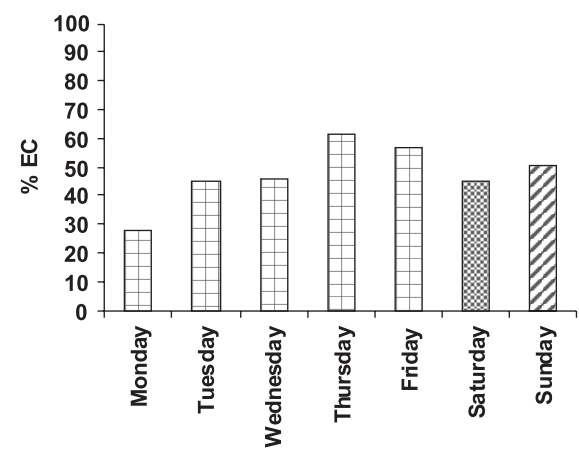

b) San Dimas

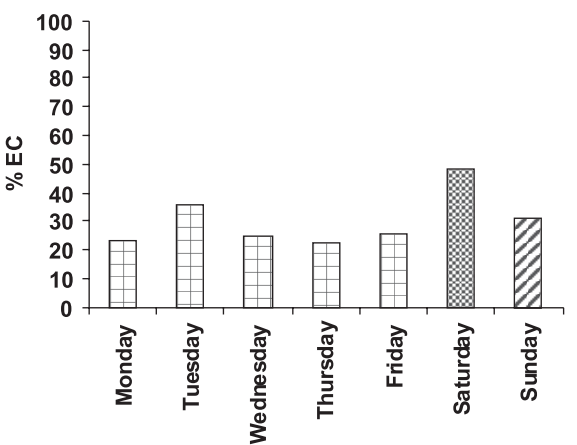

d) Long Beach

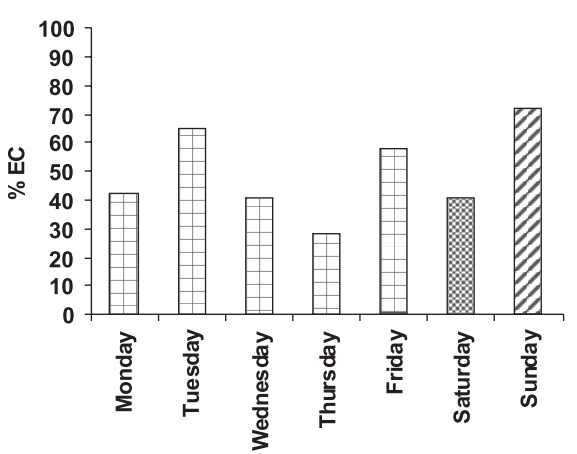

f) Lake Arrowhead

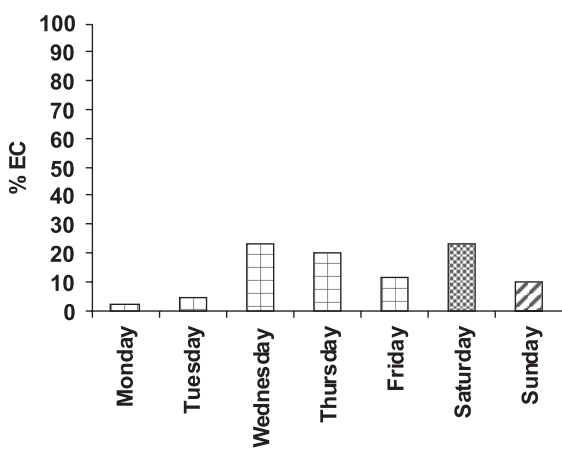

Figure 3. Average daily variability of \%EC emissions from spark ignition at different locations.

study, ${ }^{27}$ Mahnaz Hakami for her help in the preparation of sample matrices and carbon analysis, Richard Kamens, Joellen Lewtas, Pablo Cicero-Fernandez, and Susanne Hering, for their insights and helpful suggestions during the course of this study. This research was supported by the Southern California Particle Center and Supersite (USEPA Grants \#R827352-01-0 and CR-82805901) and the NIEHS Center Grant (SP30ES07048-02). Although the research described in this article has been funded wholly or in part by the United States Environmental Protection Agency, it has not been subjected to the Agency's required peer and policy review and therefore does not necessarily reflect the views of the Agency and no official endorsement should be inferred.

\section{References}

1. Miguel, A. H.; Kirchstetter, T. W.; Harley, R. A.; Hering, S. V.; Environ. Sci. Technol. 1998, 32, 450.

2. Schauer, J. J.; Kleeman, M. J.; Cass, G. R.; Simoneit, B. R. T.; Environ. Sci. Technol. 2001, 35, 1716.

3. Miguel, A. H.; Sci. Total Environ. 1984, 36, 305.

4. Gray, H. A.; Cass, G. R.; Huntzicker, J. J.; Heyerdahl, E. K.; Rau, J. A.; Environ. Sci. Technol. 1986, 20, 580.

5. Schauer, J. J.; Rogge, W. F.; Hildemann, L. M.; Mazurek, M. A.; Cass, G. R.; Atmos. Environ. 1996, 30, 3837.

6. Gray, H. A.; Cass, G. R.; Atmos. Environ. 1998, 32, 3805.

7. Allen, A. G.; Miguel, A. H.; Environ. Sci. Technol. 1995, 29, 486. 
8. Cooke, W. F.; Wilson, J. J. N.; J. Geophys. Res-Atmospheres 1996, 101, 19395

9. Charlson, R. J.; Heintzenberg, J.; Aerosol Forcing and Climate, Wiley: New York, 1995.

10. (IPCC), I. P. o. C. C.; Climate Change 1994: Radiactive Forcing of Climate Change and an Evaluation of the IPCC IS92 Emission Scenarios; Cambridge University Press: New York, 1994.

11. Venkataraman, C.; Habib, G.; Eiguren-Fernandez, A.; Miguel, A. H.; Friedlander, S. K.; Science 2005, 307, 1454.

12. (NRC), N. R. C.; Protecting Visibility in National Parks and Wilderness Areas; National Academy Press: Washington D.C., 1993.

13. Schauer, J. J.; J. Exp. Anal. Environ. Epidemiol., 2003, 13, 443.

14. Oanh, N. T. K.; Reutergardh, L. B.; Dung, N. T.; Environ. Sci. Technol. 1999, 33, 2703.

15. Daisey, J. M.; Cheney, J. L.; Lioy, P. J.; J. Air Pollut. Control Assoc. 1986, 36, 17; Rocha, G. O.; Lopes, W. A.; Pereira, P. A. P.; Vasconcellos, P. C.; Oliveira, F. S.; Carvalho, L. S.; Conceição, L. S.; de Andrade, J. B.; J. Braz. Chem. Soc. 2009, 4,680 .

16. NIOSH; Elemental Carbon (Diesel Particulate): Method 5040; $4^{\text {th }}$ ed.; NIOSH: Cincinnati, 1996.

17. Miguel, A. H.; Eiguren-Fernandez, A.; Sioutas, C.; Fine, P. M.; Geller, M.; Mayo, P. R.; Aerosol Sci. Technol. 2005, 39, 415.

18. Mastral, A. M.; Callen, M. S.; Environ. Sci. Technol. 2000, 34, 3051.

19. Peters, J. M.; Avol, E.; Gauderman, W. J.; Linn, W. S.; Navidi, W.; London, S. J.; Margolis, H.; Rappaport, E.; Vora, H.; Gong, H.; Thomas, D. C.; Am. J. Respir. Crit. Care Med. 1999, 159, 768.

20. Li, N.; Hao, M. Q.; Phalen, R. F.; Hinds, W. C.; Nel, A. E.; Clin. Immunol. 2003, 109, 250.

21. Li, N.; Sioutas, C.; Cho, A.; Schmitz, D.; Misra, C.; Sempf, J.; Wang, M. Y.; Oberley, T.; Froines, J.; Nel, A.; Environ. Health Perspect. 2003, 111, 455.
22. (US-EPA), U. S. E. P. A.; Air Quality Criteria for Particulate Matter, Second External Review Draft, US-EPA, 2001.

23. Schauer, J. J.; Kleeman, M. J.; Cass, G. R.; Simoneit, B. R. T.; Environ. Sci. Technol. 1999, 33, 1578.

24. Li, C. K.; Kamens, R. M.; Atmos. Environ., Part A 1993, 27, 523.

25. Schauer, J. J.; Kleeman, M. J.; Cass, G. R.; Simoneit, B. R. T.; Environ. Sci. Technol. 2002, 36, 1169.

26. Fujita, E. M.; Watson, J. G.; Chow, J. C.; Lu, Z. Q.; Environ. Sci. Technol. 1994, 28, 1633.

27. Eiguren-Fernandez, A.; Miguel, A. H.; Froines, J. R.; Thurairatnam, S.; Avol, E. L.; Aerosol Sci. Technol. 2004, 38, 447.

28. Birch, M. E.; Cary, R. A.; Aerosol Sci. Technol. 1996, 25, 221.

29. Eiguren-Fernandez, A.; Miguel, A. H.; Polycyclic Aromat. Compd. 2003, 23, 193.

30. Cass, G. R.; McRae, G. J.; Environ. Sci. Technol. 1983, 17, 129.

31. Friedlander, S. k.; Environ. Sci. Technol. 1973, 7, 235.

32. Miguel, A. H.; Deandrade, J. B.; Hering, S. V.; Int. J. Environ. Anal. Chem. 1986, 26, 265.

33. Venkataraman, C.; Friedlander, S. K.; Environ. Sci. Technol. 1994, 28, 563.

34. Manchester-Neesvig, J. B.; Schauer, J. J.; Cass, G. R.; J. Air Waste Manage. Assoc. 2003, 53, 1065.

35. Riddle, S. G.; Robert, M. A.; Jakober, C. A.; Hannigan, M. P.; Kleeman, M. J.; Environ. Sci. Technol. 2008, 42, 6580.

36. Fine, P. M.; Cass, G. R.; Simoneit, B. R. T.; Environ. Sci. Technol. 2001, 35, 2665.

37. Calvert, J. G.; R., A.; Becker, K. H.; Kamens, R. M.; Seinfeld, J. H.; Wallington, T. J.; Yarwood, G.; The Mechanisms of Atmospheric Oxidation of Aromatic Hydrocarbons, Oxford University Press: New York, 2002.

Received: November 24, 2008 Web Release Date: July 17, 2009 